DOI: https://doi.org/10.15688/nsr.jvolsu.2020.4.2

UDC 504+34:658

LBC 30.69

\title{
LEGAL BASIS FOR INDUSTRIAL SAFETY AND ENVIRONMENTAL PROTECTION
}

\author{
Elena A. Zaliznyak \\ Volgograd State University, Volgograd, Russian Federation \\ Sergey V. Zhbannikov \\ Volgograd State University, Volgograd, Russian Federation \\ Nataliya V. Morozova \\ Volgograd State University, Volgograd, Russian Federation
}

\begin{abstract}
Industrial enterprises and other business entities whose activities involve direct or indirect impact on environmental components must comply with legal requirements in the field of environmental protection. Over the past 5 years, there have been significant changes in environmental legislation. All objects that have a negative impact on the environment are subject to state registration. When registering an enterprise, it is subject to assignment to one of four categories of objects of negative impact, depending on the industry affiliation, production capacity, chemical composition of emissions, discharges, and other criteria. Currently, legislative innovations are aimed at business development and reducing the administrative burden on business entities, but this creates a threat to the safe operation of industrial facilities. There are more than 340 thousand objects of negative impact on the territory of Russia, of which one third is subject to Federal supervision. According to 2019 data, less than $4 \%$ of enterprises had their operational safety audits performed. The detection of violations of the requirements of legislation in the field of environmental protection, as well as failure to eliminate the identified violations, indicates the formation of potential threats to environmental safety. Taking into account the current economic crisis, in which solving environmental problems will not be a priority for business structures, the protection of the population and the natural environment is fully transferred to the state level.
\end{abstract}

Key words: industrial safety, object of negative impact, environmental legislation, state environmental supervision

Citation. Zaliznyak E.A., Zhbannikov S.V., Morozova N.V. Legal Basis for Industrial Safety and Environmental Protection. Natural Systems and Resources, 2020, vol. 10, no. 4, pp. 12-21. DOI: https://doi.org/10.15688/ nsr.jvolsu.2020.4.2

УДК 504+34:658

ББК 30.69

ПРАВОВЫЕ ОСНОВЫ ОБЕСПЕЧЕНИЯ ПРОМЫШЛЕННОЙ БЕЗОПАСНОСТИ И ОХРАНЫ ОКРУЖАЮЩЕЙ СРЕДЫ

Елена Алексеевна Зализняк

Волгоградский государственный университет, г. Волгоград, Российская Федерация

Сергей Викторович Жбанников

Волгоградский государственный университет, г. Волгоград, Российская Федерация

Наталия Владимировна Морозова

Волгоградский государственный университет, г. Волгоград, Российская Федерация 
Аннотация. Промышленные предприятия и иные субъекты хозяйствования, деятельность которых связана с прямым или косвенным воздействием на компоненты окружающей среды, должны выполнять законодательные требования в области охраны окружающей среды. За последние 5 лет произошли существенные изменения природоохранного законодательства. Все объекты, оказывающие негативное воздействие на окружающую среду, подлежат государственному учету. При постановке на учет предприятие подлежит отнесению к одной из четырех категорий объектов негативного воздействия, в зависимости от отраслевой принадлежности, производственной мощности, химического состава выбросов, сбросов и иных критериев. В настоящее время законодательные нововведения направлены на развитие бизнеса и снижение административной нагрузки на субъекты хозяйствования, но при этом создается угроза безопасного функционирования промышленных объектов. На территории России более 340 тыс. объектов негативного воздействия, из них одна треть подлежит федеральному надзору. По данным 2019 года, проверки безопасности функционирования были проведены менее чем у 4 \% предприятий. Выявление нарушений требований законодательства в области охраны окружающей среды, а также неустранение выявленных нарушений свидетельствуют о формировании потенциальных угроз экологической безопасности. Учитывая текущий экономический кризис, при котором решение экологических проблем не будет первоочередной задачей бизнес-структур, защита населения и окружающей природной среды полностью переходит на государственный уровень.

Ключевые слова: промышленная безопасность, объект негативного воздействия, природоохранное законодательство, государственный экологический надзор.

Цитирование. Зализняк Е. А., Жбанников С. В., Морозова Н. В. Правовые основы обеспечения промышленной безопасности и охраны окружающей среды // Природные системы и ресурсы. - 2020. - Т. 10, № 4. - C. 12-21. - DOI: https://doi.org/10.15688/nsr.jvolsu.2020.4.2

В соответствии с законодательно установленными принципами охраны окружающей среды, воздействие промышленных предприятий и иных объектов хозяйствования допускается исходя из требований в области охраны окружающей среды.

Объект, оказывающий негативное воздействие на окружающую среду (НВОС), объект капитального строительства и (или) другой объект, а также их совокупность, объединенные единым назначением и (или) неразрывно связанные физически или технологически и расположенные в пределах одного или нескольких земельных участков [10].

Требования к хозяйствующим субъектам, в части охраны окружающей среды, при функционировании предприятий и других объектов, деятельность которых связана с оказанием прямого либо косвенного воздействия на компоненты среды, закреплены в федеральном законе «Об охране окружающей среды». В процессе эксплуатации объектов НВОС должны выполняться следующие условия:

- соблюдение утвержденных технологий;

- проведение мероприятий по воспроизводству природных ресурсов и их рациональному использованию;

- обеспечение экологической безопасности;
- соответствие установленным нормативам качества ОC; нологий;

- применение наилучших доступных тех-

- соблюдение иных требований по охране OC.

Все объекты НВОС подлежат государственному учету (см. рис. 1).

Объекты НВОС в зависимости от уровня воздействия на компоненты окружающей среды подразделяются на четыре категории (см. рис. 2).

Критерии отнесения объектов, оказывающих негативное воздействие на окружающую среду, к объектам НВОС представлены на рисунке 3 .

В зависимости от мощности производства, отраслевой принадлежности, класса опасности и уровня токсичности веществ, содержащихся в выбросах или сбросах предприятия, объекты НВОС, с аналогичными производственными процессами, могут быть отнесены к разным категориям воздействия (см. рис. 4).

Как видно по данным рисунка 5, предприятия, выпускающие аналогичную продукцию, но имеющие различную мощность производства, будут относиться к разным категориям объектов негативного воздействия. Например, завод по производству строитель- 


\section{ЭКОЛОГИя И БИОЛОГИя}

ных керамических материалов, с мощностью производства менее 1 млн штук в год будет отнесен ко II категории объектов НВОС, в слу- чае, если проектная мощность такого предприятия будет выше, объект будет отнесен к I категории.

\begin{tabular}{|c|c|}
\hline \multirow{4}{*}{$\begin{array}{l}\text { Задачи учета } \\
\text { объектов } \\
\text { НВОС }\end{array}$} & получение достоверной информации об объектах \\
\hline & определение областей применения НДТ \\
\hline & применение программно-целевых методов планирования \\
\hline & $\begin{array}{l}\text { планирование осуществления государственного экологического } \\
\text { надзора }\end{array}$ \\
\hline
\end{tabular}

Рис. 1. Задачи государственного учета объектов негативного воздействия Примечание. Составлено по: [8].

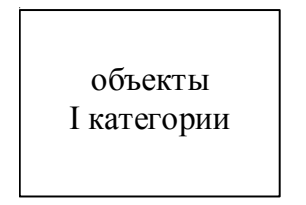

оказывающие значительное негативное воздейст-
вие на ОС и относящиеся к областям применения
наилучши доступных технологий - подлежат Фе-
деральному надзору

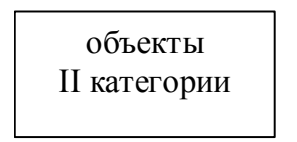

объекты, оказывающие умеренное негативное воздействие на окружающую среду

объекты
III категории

$$
\begin{aligned}
& \text { объекты, оказывающие незначительное негативное } \\
& \text { воздействие на окружающую среду }
\end{aligned}
$$

$$
\begin{gathered}
\text { объекты } \\
\text { IV категории }
\end{gathered}
$$

\begin{tabular}{|c|c|}
\hline \multirow{3}{*}{$\begin{array}{l}\text { Критерии } \\
\text { категоризации } \\
\text { объектов НВОС }\end{array}$} & $\begin{array}{l}\text { уровни воздействия на окружающую среду видов хозяйственной и } \\
\text { (или) иной деятельности (отрасль, часть отрасли, производство) }\end{array}$ \\
\hline & $\begin{array}{l}\text { уровень токсичности, канцерогенные и мутагенные } \\
\text { загрязняющих веществ, содержащихся в выбросах, } \\
\text { загрязняющих веществ, а также классы опасности } \\
\text { проходов } \\
\text { произодства и потребления }\end{array}$ \\
\hline & $\begin{array}{l}\text { классификация промышленных объектов и производств; особенности } \\
\text { осуществления деятельности в области использования атомной } \\
\text { энергии }\end{array}$ \\
\hline
\end{tabular}

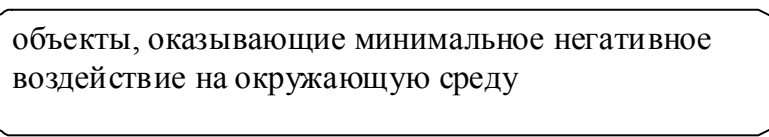

Рис. 2. Категоризация объектов НВОС

Примечание. Составлено по: [9].

Рис. 3. Критерии отнесения объектов, оказывающих негативное воздействие на окружающую среду, к объектам I, II, III и IV категорий

Примечание. Составлено по: [7]. 


\begin{tabular}{|c|c|}
\hline & $\begin{array}{l}\text { по переработке и консервированию мяса в части, касающейся выполнения работ } \\
\text { по убою животных на мясокомбинатах, мясохладобойнях; } \\
\text { по добыче угля; } \\
\text { по разведению сельскохозяйственной птицы (с проектной мощностью } 40 \text { тыс. } \\
\text { птицемест и более); } \\
\text { по добыче сырой нефти и природного газа, включая переработку природного газа } \\
\text { и др.; }\end{array}$ \\
\hline & $\begin{array}{l}\text { птицефабрика с проектной мощностью менее } 40 \text { тыс. птицемест } \\
\text { порт, расположенным на внутренних водных путях РФ (допускающим проход } \\
\text { судов водоизмещением } 1350 \text { тонн и более); } \\
\text { деятельность по производству ядерного топлива; } \\
\text { производство огнеупорных керамических изделий и строительных керамических } \\
\text { материалов (с проектной мощностью менее } 1 \text { млн. штук в год) и др.; }\end{array}$ \\
\hline & $\begin{array}{l}\text { по эксплуатации исследовательских ядерных установок нулевой мощности, } \\
\text { радиационных источников, содержащих в своем составе только радионуклидные } \\
\text { источники } 4 \text { и } 5 \text { категорий. } \\
\text { осуществление хозяйственной и (или) иной деятельности, не указанной в I, II и IV } \\
\text { категориях и не соответствующей уровням воздействия на ОС, определенным для } \\
4 \text { категории. }\end{array}$ \\
\hline & $\begin{array}{l}\text { наличие на объекте стационарных источников загрязнения ОС, масса } \\
\text { загрязняющих веществ в выбросах в атмосферный воздух которых не превышает } \\
10 \text { тонн в год, при отсутствии в составе выбросов веществ I и II классов } \\
\text { опасности, радиоактивных веществ; } \\
\text { отсутствие сбросов загрязняющих веществ в составе сточных вод в } \\
\text { централизованные системы водоотведения, другие сооружения и системы } \\
\text { отведения и очистки сточных вод, за исключением сбросов загрязняющих } \\
\text { веществ, образующихся в результате использования вод для бытовых нужд, а } \\
\text { также отсугствие сбросов загрязняющих веществ в окружающую среду. }\end{array}$ \\
\hline
\end{tabular}

Рис. 4. Примеры объектов НВОС по категориям

Примечание. Составлено автором по: [7].

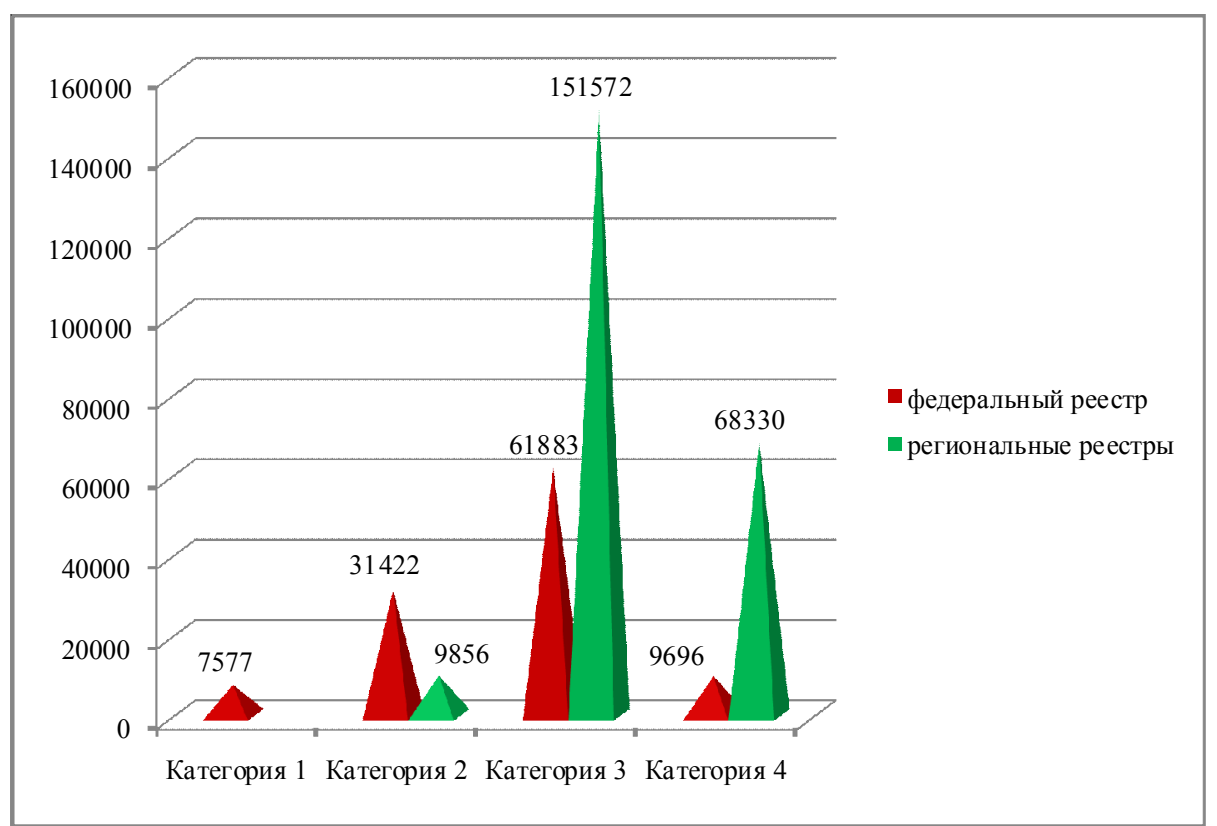

Рис. 5. Количество объектов негативного воздействия в реестрах по категориям (по состоянию на декабрь 2020 г.)

Примечание. Составлено по: [4]. 
По состоянию на 31.12.2019 г. количество объектов, оказывающих негативное воздействие на окружающую среду и подлежащих федеральному государственному экологическому надзору, составляло 102 505. Плановые проверки в 2019 году проведены в отношении 3837 объектов, оказывающих негативное воздействие на окружающую среду [3]. Таким образом, Росприроднадзором проверяется лишь менее $4 \%$ объектов негативного воздействия. С одной стороны, в целях сокращения административного давления на хозяйствующие субъекты количество плановых проверок в отношении субъектов хозяйствования ежегодно снижается, но, с другой стороны, антропогенная нагрузка на компоненты среды в РФ ежегодно растет. Так, в Приоритетный список городов с наибольшим уровнем загрязнения воздуха в Российской Федерации в 2018 г. включены 22 города, что на 4,8 \% выше уровня 2017 г., уровень загрязнения воздуха в 2018 г. оценивался как высокий и очень высокий (ИЗА > 7). За период 2014-2018 гг., по данным регулярных наблюдений, средние за год концентрации бенз(а)пирена и формальдегида увеличились на 4-9\%. Суммарные выбросы от стационарных и передвижных источников оксида углерода - увеличились на $8 \%$ [1]. Число случаев высокого и экстремально высокого загрязнения атмосферного воздуха и водных объектов в 2019 году увеличилось на $10 \%$ и превысил ежегодные показатели начиная с 2015 года (рис. 6).

По данным государственного реестра объектов негативного воздействия на окружающую среду (НBOC), на территории Волгоградской области по состоянию на 01.012020 г. зарегистрировано 1589 объектов федерального уровня государственного экологического надзора, из которых 109 $(6,9 \%)$ относится к I категории - объектам, оказывающим значительное негативное воздействие на окружающую среду и относящихся к областям применения НДТ, и 3257 объектов НВОС регионального уровня надзора (см. рис. 7).

В настоящее время промышленность Волгоградской области представляет собой развитый многоотраслевой комплекс, включающий в себя отрасли черной и цветной металлургии, машиностроения и металлообработки, нефтяной и нефтеперерабатывающей, химической и нефтехимической промышленности, производство строительных материалов, а также отрасли легкой и пищевой промышленности.

Доминирующее положение в структуре промышленного комплекса региона занимают обрабатывающие производства, на долю которых приходится 85,3 \% производимой продукции.

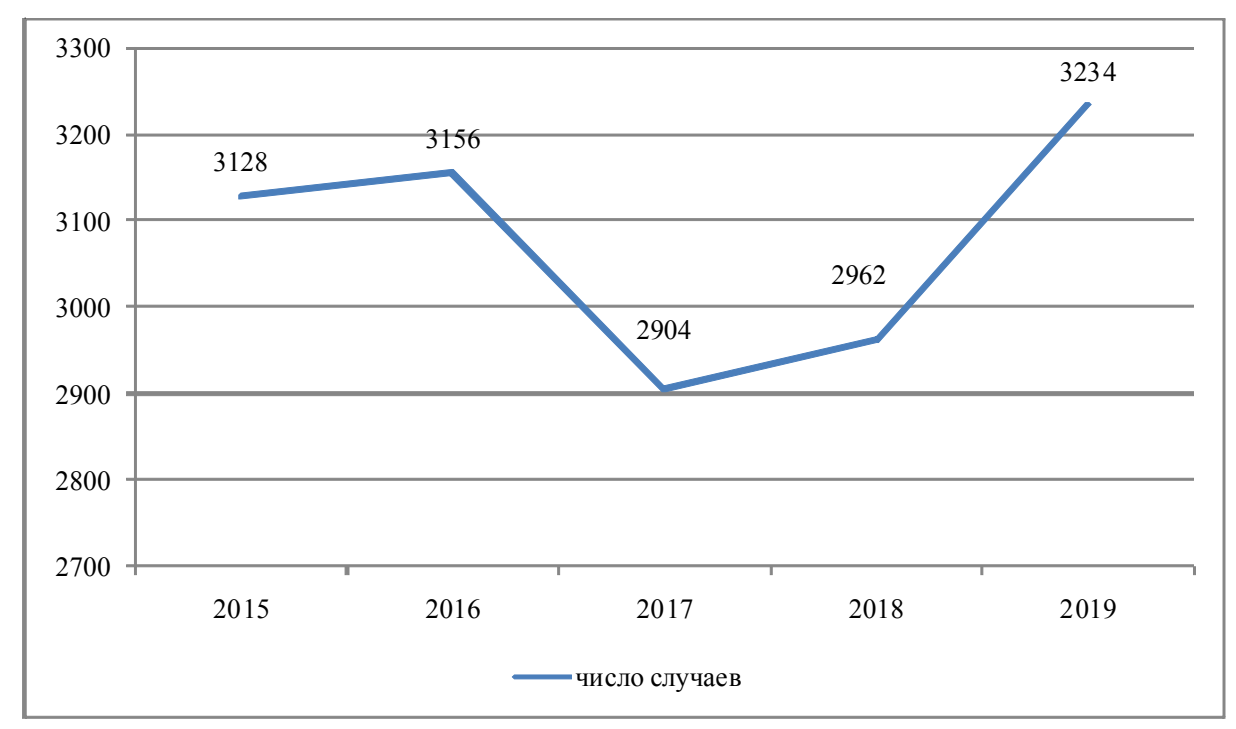

Рис. 6. Число случаев высокого и экстремально высокого загрязнения атмосферного воздуха и водных объектов

Примечание. Составлено по: [6]. 


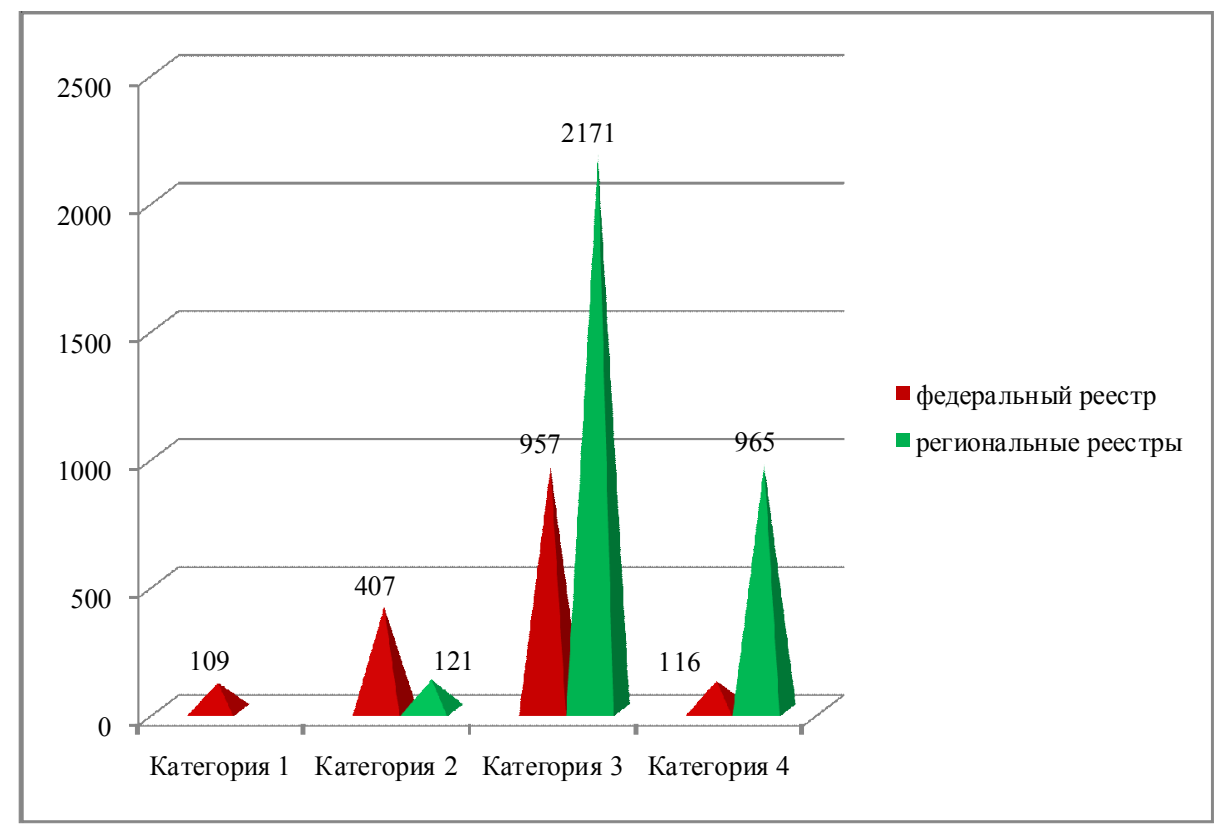

Рис. 7. Количество объектов НВОС на территории Волгоградской области по состоянию на 01.012020 г.

Примечание. Составлено автором по: [4].

Среди обрабатывающих производств наибольший объем выпускаемой продукции приходится на производство кокса и нефтепродуктов - 45 \%. Крупнейшими производителями этой отрасли в регионе являются дочерние компании ПАО «ЛУКОЙЛ» - ООО «ЛУКОЙЛ-Волгограднефтепереработка», выпускающее более 80 наименований нефтепродуктов и ООО «ЛУКОЙЛ - Коробковский газоперерабатывающий завод», специализирующийся на выпуске отбензиненного газа, бензина газового стабильного и сжиженных углеводородных газов.

20 \% объема выпускаемой продукции обрабатывающих производств Волгоградской области обеспечивает металлургический комплекс, включающий в себя более 360 предприятий. Среди предприятий региона наибольший объем производства обеспечивают $\mathrm{AO}$ «Волжский трубный завод», Филиал $\mathrm{AO}$ «РУСАЛ Урал» в Волгограде «Объединенная компания РУСАЛ Волгоградский алюминиевый завод» и др.

В области работает 336 предприятий, занимающихся производством различных химических веществ и химических продуктов. Безусловными лидерами химической отрасли в регионе являются АО «КАУСТИК», АО «НикоМаг», ООО «ЕвроХимВолгаКалий», АО «Волжский Оргсинтез»,
Волгоградский филиал ООО «Омсктехуглерод», АО «ВОЛТАЙР-ПРОМ», ООО «Волгопромтранс», АО «Волжскрезинотехника», ООО «Зиракс».

4 предприятия Волгоградской области $\mathrm{AO}$ «Себряковцемент», ООО «ЛУКОЙЛ-Волгограднефтепереработка», ОАО «Волжский абразивный завод» и ООО «Концессии водоснабжения», согласно приказу Министерства природных ресурсов и экологии РФ от 18.042018 г. № 154 «Об утверждении перечня объектов, оказывающих негативное воздействие на окружающую среду, относящихся к I категории, вклад которых в суммарные выбросы, сбросы загрязняющих веществ в Российской Федерации составляет не менее чем 60 процентов», вошли в перечень объектов НВОС I категории, вносящих не менее $60 \%$ объема в суммарные выбросы, сбросы загрязняющих веществ в Российской Федерации.

Предприятия, относящиеся к 1 категории объектов НВОС, подлежат федеральному экологическому надзору. Эффективность обеспечения безопасного функционирования объекта НВОС можно оценить путем анализа нарушений хозяйствующим субъектом законодательно установленных требований. Например, Межрегиональным управлением Росприроднадзора по Астра- 


\section{ЭкоЛОГИЯ И БИоЛОГИя}

ханской и Волгоградской областям в 2019 году в отношении $\mathrm{AO}$ «ВМК “Красный Октябрь”» проведена плановая выездная проверка, в ходе которой установлены факты осуществления АО «ВМК “Красный Октябрь”» производственной деятельности в отсутствие специального разрешения на выброс вредных (загрязняющих) веществ в атмосферный воздух, непредставления в уполномоченный орган информации о состоянии окружающей среды, невнесения платы за негативное воздействие на окружающую среду и прочее. Основной проблемой АО «ВМК “Красный Октябрь”» является выброс загрязняющих веществ от ЭСПЦ-2 и отсутствие эффективной очистки от сталеплавильной печи (ДСП-5).

По результатам выявленных нарушений юридическое и должностное лица АО «ВМК “Красный Октябрь”» привлечены к административной ответственности по ст. 8.1, ч. 7 ст. 8.2 , ст. 8.5 , ч. 1 ст. 8.21 , ст. 8.41 КоАП РФ, в адрес юридического лица АО «ВМК “Красный Октябрь”» выдано предписание об устранении выявленных нарушений обязательных требований и вынесены представления об устранении причин и условий, способствовавших совершению административных правонарушений. Общая сумма штрафных санкций составила 456 тыс. руб. Информация о результатах проведенной проверки направлена Межрегиональным управлением в ноябре 2019 года в Волгоградскую межрайонную природоохранную прокуратуру для принятия мер прокурорского реагирования и УФСБ России по Волгоградской области [2]. В июле 2020 года было выявлено, что решение Краснооктябрьского районного суда Волгоградской области по иску Волгоградской межрайонной природоохранной прокуратуры об обязании АО «ВМК "Красный Октябрь”» выполнить техническое перевооружение ЭСПЦ-2, в связи с длящимися процедурами банкротств на предприятии, до настоящего времени не исполнено [5]. Следовательно, данный объект НВОС не соблюдает требования, предъявляемые к субъектам хозяйствования в части обеспечения безопасного функционирования и представляет угрозу для населения и окружающей природной среды.
На региональном уровне государственный экологический надзор, на территории Волгоградской области, осуществляет комитет природных ресурсов, лесного хозяйства и экологии Волгоградской области. В рамках своих полномочий комитет проводит проверки хозяйствующих субъектов, за исключением объектов НВОС, подлежащих федеральному государственному экологическому надзору. В 2019 году комитетом было проведено более 2000 мероприятий по надзору в сфере охраны окружающей среды, из которых 33 плановые проверки [2]. Таким образом, из 3257 объектов НВОС, регионального уровня надзора, комитет запланировал проверку лишь $1 \%$ хозяйствующих субъектов, наносящих вред окружающей среде.

За нарушение законодательства в области охраны окружающей среды устанавливается имущественная, дисциплинарная, административная и уголовная ответственность.

Анализируя данные по числу наказаний за нарушения в области охраны окружающей среды, можно отметить, что в 2019 году их количество сократилось на $8 \%$ по сравнению с предыдущим годом. Общее количество административных и уголовных наказаний природоохранного законодательства составило более 270000 за последние 5 лет (см. рис. 8).

Необходимо отметить, что в вопросе обеспечения безопасного функционирования объектов НВОС важно учитывать, что снижение административной нагрузки для бизнеса, не должно создавать потенциальных угроз экологической безопасности. Требуется четкое разграничение потенциальных рисков и государственного надзора в зависимости от категории предприятия и профиля деятельности (особому и регулярному контролю должны подлежать потенциально опасные производства, предприятия 1 категории объектов НВОС). Это особенно актуально в настоящее время, поскольку в период кризиса, представители бизнес структур акцентируют свое внимание на обеспечение своей финансовой устойчивости, отодвигая в сторону обеспечение экологической безопасности. 


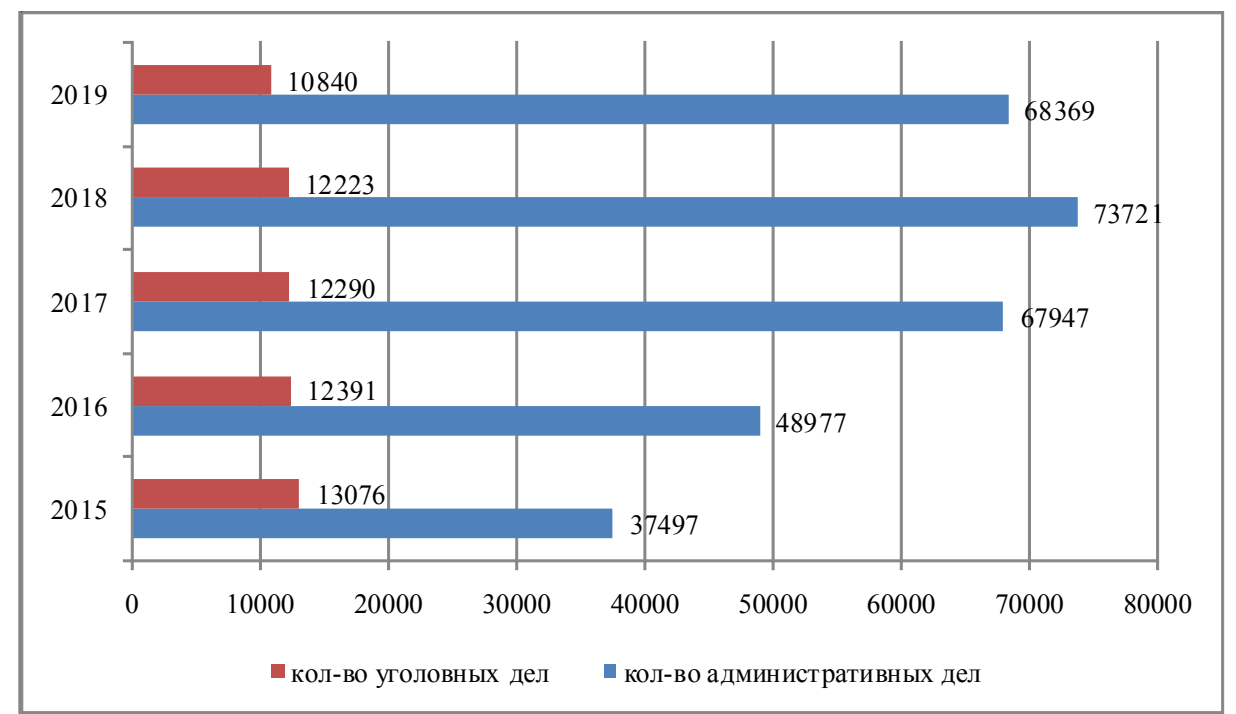

Рис. 8. Динамика административных и уголовных дел в области охраны окружающей среды Примечание. Составлено по: [11].

\section{СПИСОК ЛИТЕРАТУРЫ}

1. Государственный доклад «О состоянии и об охране окружающей среды Российской Федерации в 2018 году» // Минприроды России. - Электрон. дан. - Режим доступа: https://gosdokladecology.ru/2018/atmosfernyy-vozdukh/kachestvoatmosfernogo-vozdukha/ (дата обращения: 07.12.2020). - Загл. с экрана.

2. Доклад «О состоянии окружающей среды Волгоградской области в 2019 году» / ред. колл.: В. Е. Сазонов [и др.] ; Комитет природных ресурсов, лесного хозяйства и экологии Волгоградской области. - Электрон. дан. - Волгоград: ТЕМПОРА, 2020. - 300 c. - Режим доступа: https://oblkompriroda. volgograd.ru/upload/iblock/65e/Ekologiya_2020_.pdf (дата обращения: 08.12.2020). - Загл. с экрана.

3. Доклад Федеральной службы по надзору в сфере природопользования об осуществлении государственного контроля (надзора), муниципального контроля в соответствующих сферах деятельности и об эффективности такого контроля за 2019 год. Электрон. дан. - Режим доступа: https://rpn.gov.ru/ upload/iblock/646/646a2100f55539327a2c8b68a $2 \mathrm{cca} 5 \mathrm{~d} 3 . p d f$ (дата обращения: 06.12.2020). - Загл. с экрана.

4. Количество объектов в реестрах по категориям // ПТО УОНВОС - публичный реестр объектов негативного воздействия на окружающую среду. - Электрон. дан. - Режим доступа: https:// onv.fsrpn.ru/\#/ (дата обращения: 10.12.2020). - Загл. с экрана.

5. Мероприятия в отношении предприятия загрязнителя г. Волгограда АО «ВМК "Красный Октябрь”» // Федеральная служба по надзору и сфе- ре природопользования от 31.07.2020. - Электрон. дан. - Режим доступа: https://rpn.gov.ru/regions/30/ news/meropriyatiya_v_otnoshenii_predpriyatiya zagryaznitelya_g_volgograda_ao_vmk_krasnyy_oktyabr62819.html (дата обращения: 10.12.2020). - Загл. с экрана.

6. Обзор состояния и загрязнения окружающей среды в Российской Федерации // Федеральная служба по гидрометеорологии и мониторингу окружающей среды (Росгидромет) : официальный сайт. - Электрон. дан. - Режим доступа: http:// www.meteorf.ru/product/infomaterials/90/?year= 2018\&ID=90 (дата обращения: 08.12.2020). - Загл. с экрана.

7. Постановление Правительства РФ от 28.09.2015 № 1029 «Об утверждении критериев отнесения объектов, оказывающих негативное воздействие на окружающую среду, к объектам I, II, III и IV категорий». - Электрон. дан. - Режим доступа: http://www.consultant.ru/document/cons_doc LAW_186693/(дата обращения: 09.12.2020). -Загл. с экрана.

8. Федеральный закон от 10.01.2002 № 7-Ф3 «Об охране окружающей среды» ст. 69. Государственный учет объектов, оказывающих негативное воздействие на окружающую среду. - Электрон. дан. - Режим доступа: http://www.consultant.ru/ document/cons_doc_LAW_34823/d65d73d7b 38868424f4022d39a0515bf9a79046d/ (дата обращения: 07.12.2020). - Загл. с экрана.

9. Федеральный закон от 10.01.2002 № 7-Ф3 «Об охране окружающей среды». - Электрон. дан. - Режим доступа: http://www.consultant.ru/ document/cons_doc_LAW_34823/ (дата обращения: 07.12.2020). - Загл. с экрана. 
10. Федеральный закон от 21.07.2014 № 219- Ф3 «О внесении изменений в Федеральный закон “Об охране окружающей среды” и отдельные законодательные акты Российской Федерации». - Электрон. дан. - Режим доступа: http://www.consultant.ru/ document/cons_doc_LAW_165823/ (дата обращения: 05.12.2020). - Загл. с экрана.

11. Экобезнаказанность: количество наказаний за экологические правонарушения снизилось до трехлетнего минимума // ФинЭкспертиза - сеть профессиональных аудиторских, оценочных и консалтинговых компаний. - Электрон. дан. - Режим доступа: https://finexpertiza.ru/press-service/ researches/2020/ekobeznakazannost/ (дата обращения: 10.12.2020). - Загл. с экрана.

\section{REFERENCES}

1. Gosudarstvennyy doklad "O sostoyanii i ob okhrane okruzhayushchey sredy Rossiyskoy Federatsii v 2018 godu". Minprirody Rossii. URL: https://gosdoklad-ecology.ru/2018/atmosfernyyvozdukh/kachestvo-atmosfernogo-vozdukha/ (accessed 07.12.2020).

2. V.Ye. Sazonov et al., eds. Doklad "O sostoyanii okruzhayushchey sredy Volgogradskoy oblasti v 2019 godu”. Volgograd, TEMPORA Publ., 2020. 300 p. URL: https:// oblkompriroda.volgograd.ru/upload/iblock/65e/ Ekologiya_2020_.pdf (accessed 08.12.2020).

3. Doklad Federalnoy sluzhby po nadzoru $v$ sfere prirodopolzovaniya ob osushchestvlenii gosudarstvennogo kontrolya (nadzora), munitsipal'nogo kontrolya v sootvetstvuyushchikh sferakh deyatel'nosti $i$ ob effektivnosti takogo kontrolya za 2019 god. URL: https://rpn.gov.ru/ upload/iblock/646/646a2100f55539327a2c8b68a 2cca5d3.pdf (accessed 06.12.2020).

4. Kolichestvo obyektov $v$ reyestrakh po kategoriyam. PTO UONVOS - publichnyy reyestr obyektov negativnogo vozdeystviya na okruzhayushchuyu sredu. URL: https://onv.fsrpn.ru/\#/ (accessed 10.12.2020).
5. Meropriyatiya $\mathrm{v}$ otnoshenii predpriyatiya zagryaznitelya g. Volgograda AO «VMK "Krasnyy Oktyabr"». Federalnaya sluzhba po nadzoru i sfere prirodopol'zovaniya ot 31.07.2020. URL: https://rpn. gov.ru/regions/30/news/meropriyatiya_v_otnoshenii_ predpriyatiya_zagryaznitelya_g_volgograda_ao_vmk_ krasnyy_oktyabr-62819.html (accessed 10.12.2020).

6. Obzor sostoyaniya i zagryazneniya okruzhayushchey sredy v Rossiyskoy Federatsii. Federalnaya sluzhba po gidrometeorologii $i$ monitoringu okruzhayushchey sredy (Rosgidromet). URL: http:/www.meteorf.ru/product/infomaterials/90/ ?year $=2018 \& \mathrm{ID}=90$ (accessed 08.12.2020).

7. Postanovleniye Pravitelstva RF ot 28.09.2015 № 1029 "Ob utverzhdenii kriteriyev otneseniya obyektov, okazyvayushchikh negativnoye vozdeystviye na okruzhayushchuyu sredu, $k$ ob "yektam I, II, III i IV kategoriy". URL: http://www. consultant.ru/document/cons_doc_LAW_186693/ (accessed 09.12.2020).

8. Federal'nyy zakon ot 10.01.2002 № 7-FZ "Ob okhrane okruzhayushchey sredy" st. 69. Gosudarstvennyy uchet obyektov, okazyvayushchikh negativnoye vozdeystviye na okruzhayushchuyu sredu. URL: http://www.consultant.ru/document/ cons_doc_LAW 34823/d65d73d7b38868424f 4022d39a0515bf9a79046d/ (accessed 07.12.2020).

9. Federal'nyy zakon ot 10.01.2002 № 7-FZ "Ob okhrane okruzhayushchey sredy". URL: http:// www.consultant.ru/document/cons_doc_LAW_ 34823/ (accessed 07.12.2020).

10. Federalnyy zakon ot 21.07.2014 № 219- FZ "O vnesenii izmeneniy $v$ Federal'nyy zakon "Ob okhrane okruzhayushchey sredy" $i$ otdel'nyye zakonodatel'nyye akty Rossiyskoy Federatsii". URL: http://www.consultant.ru/document/cons_doc_ LAW_165823/(accessed 05.12.2020).

11. Ekobeznakazannost: kolichestvo nakazaniy za ekologicheskiye pravonarusheniya snizilos do trekhletnego minimuma. FinEkspertiza - set' professional'nykh auditorskikh, otsenochnykh $i$ konsaltingovykh kompaniy. URL: https://finexpertiza. ru/press-service/researches/2020/ekobeznakazannost/ (accessed 10.12.2020). 


\section{Information About the Authors}

Elena A. Zaliznyak, Senior Lecturer, Department of Ecology and Environmental Management, Volgograd State University, Prosp. Universitetsky, 100, 400062 Volgograd, Russian Federation, Elena.zaliznyak@mail.ru, econecol@volsu.ru

Sergey V. Zhbannikov, Associate Professor, Department of Ecology and Environmental Management, Volgograd State University, Prosp. Universitetsky, 100, 400062 Volgograd, Russian Federation, econecol@volsu.ru

Nataliya V. Morozova, Candidate of Sciences (Engineering), Associate Professor, Department of Ecology and Environmental Management, Volgograd State University, Prosp. Universitetsky, 100, 400062 Volgograd, Russian Federation, econecol@volsu.ru

\section{Информация об авторах}

Елена Алексеевна Зализняк, старший преподаватель кафедры экологии и природопользования, Волгоградский государственный университет, просп. Университетский, 100, 400062 г. Волгоград, Российская Федерация, Elena.zaliznyak@mail.ru, econecol@volsu.ru

Сергей Викторович Жбанников, доцент кафедры экологии и природопользования, Волгоградский государственный университет, просп. Университетский, 100, 400062 г. Волгоград, Российская Федерация, econecol@volsu.ru

Наталия Владимировна Морозова, кандидат технических наук доцент кафедры экологии и природопользования, Волгоградский государственный университет, просп. Университетский, 100, 400062 г. Волгоград, Российская Федерация, econecol@volsu.ru 